\title{
Conflicts of Law, Federalism, and Institutional Competence
}

\author{
Lee Farnsworth ${ }^{*}$
}

INTRODUCTION

This Article deals primarily with choice-of-law problems in state and federal courts. A subset of the broader issues of conflict of laws, choice of law involves the decision regarding which substantive legal rule(s) will apply in a particular case. While that decision can be straightforward in cases involving parties from only one state and events that occurred in that same state, problems quickly emerge when, for example, parties are from different states or the events giving rise to the suit occurred in a state other than the forum state.

Historically, courts confronted with tricky choice-of-law problems have used different approaches to determine which law to apply. Choice of law has, in all but two states, ${ }^{1}$ developed as a common law doctrine of state law. And up until the mid-twentieth century, states' choice-of-law provisions developed with an eye toward respecting the territorial sovereignty of the place where a legal right was thought to have vested. This "vested rights" approach emphasized different territorial rules for different areas of law. ${ }^{2}$

Around the middle of the twentieth century, however, scholars and judges grew discontent with the rigid formalism of the vested rights approach. ${ }^{3}$ If, for example, two citizens of state A just happened to get into a car accident while driving in state $\mathrm{B}$, but brought suit in the courts of state A, why should the law of state B control? While the accident

\footnotetext{
* Litigation associate, Sidley Austin LLP, Chicago; J.D. with high honors, 2019, University of Chicago Law School. I would like to thank Professor William Baude, Chief Judge Diane Wood, and the staff of the Kansas Law Review for their helpful comments on earlier drafts of this piece and Rachel Granetz for constant assistance, editorial and otherwise. The views in this Article are my own and do not necessarily reflect those of Sidley Austin LLP or its clients.

1. Louisiana and Oregon have statutorily mandated choice-of-law rules. See generally James A.R. Nafziger, The Louisiana and Oregon Codifications of Choice-of-Law Rules in Context, 58 AM. J. COMP. L. 165 (2010).

2. See infra Part I.

3. See infra Section II.A.
} 
occurred in that state, every other factor in the case (the domicile of both parties and the forum) point to the application of state A's law. Motivated by these sorts of intuitions, courts began moving away from a territorial approach to conflicts and toward other methods for choice-oflaw analysis that focused on the contacts of each state with the dispute, the interest that each state had in seeing its law applied to govern a particular case, or the relative merits of the substantive laws in question (abstracted away from the particulars of the specific case).

These new approaches were not without their own problems. The newer choice-of-law schemes gave judges more flexibility to apply the law of the state most connected to a controversy overall, ${ }^{4}$ rather than the law of the state where the last act giving rise to the cause of action occurred. But with these changes came the concern that the new approaches gave judges too much latitude to engage in state-based favoritism, promoting the interests of their forum states or showing preference for their forum states' own citizens. Indeed, some of the new theories were expressly premised on the idea that state legislation was designed to protect the interests of state residents and not outsiders and that judges should give effect to that legislative intent.

Seeking to mollify these concerns about the favoritism of state court judges, at least one early proponent of the new choice-of-law approaches proposed an additional procedural innovation. ${ }^{5}$ According to this view, while choice of law should be sensitive to the relative interests of the states whose law might be applied in a given case, state court judges should not themselves consider those interests. Instead, federal judges, who are life-tenured, federal rather than state actors, and perhaps therefore more neutral than state judges, ought to make choice-of-law determinations.

This Article considers that procedural suggestion. In particular, this Article examines the merits of having federal judges, rather than state court judges, make choice-of-law determinations under nonterritorial choice-of-law approaches. ${ }^{6}$ The Article then considers the procedural mechanisms that might be created to facilitate such a review, as well as

4. Indeed, judicial flexibility under the newer systems is even greater than this sentence suggests, as some conflicts systems allow judges to make choice-of-law determinations issue-byissue rather than for the controversy as a whole. The process of dividing up a case into separate issues, each presenting its own choice-of-law question, is known as "dépeçage." Dépeçage is inconsistent with the First Restatement. See, e.g., Simon v. United States, 805 N.E.2d 798, 801-03 (Ind. 2004). But some later theories do embrace the practice. See, e.g., RESTATEMENT (SECOND) OF CONFLICT OF LAWS $§ 145$ (AM. LAW INST. 1971).

5. See infra Section II.D.

6. See infra Section III.A. 
the conceptual benefits and drawbacks of assigning federal courts this role. This Article will also consider how this vision of federal court involvement in choice-of-law decisions squares with the Constitution, particularly with the Supreme Court's holding that federal courts sitting in diversity must apply state, rather than federal, conflicts law.

This Article has four parts. Part I lays out the basics of the traditional territorial approach to choice of law. Part II briefly summarizes the move away from territoriality and toward consideration of state interests and contacts. With this shift came a greater role for judges. Interest- or contacts-based systems require judges to evaluate two or more states' competing interests in a particular case. That evaluation includes consideration of state policy goals and a judgment about the fit between a broad state policy and the facts of a particular case. The evolution of conflicts from rigid territoriality to evaluation of state interests and purposes continues to this day, as the Draft Restatement (Third) of Conflicts of Law illustrates.

Because such evaluation can be highly sensitive to the importance placed on a particular state's policy goals, Part III examines the mechanisms by which we might move conflicts consideration to federal courts. Those mechanisms require reviewing conflicts' place under the Erie doctrine and potential congressional authority to create uniform conflicts law under the Constitution's Full Faith and Credit Clause. Part IV then advances a specific proposal for federal court determination of choice-of-law questions. This Article suggests that a state appellate courts faced with a choice-of-law decision based on state interests or similar concerns should certify such a question to a federal court of appeals for resolution in a neutral federal forum. Part IV also considers potential concerns associated with such a proposal.

\section{TRADitional CHOICE OF LAW AND VESTED RightS}

Early American choice-of-law theory focused on a territorial approach. ${ }^{7}$ When faced with a situation in which multiple states might reasonably be thought to have some claim to the application of their laws to a particular dispute, early theory resolved the conflict in favor of the state in which a legal right had arisen. This so-called vested rights approach derived from a strong sense of the territorial sovereignty of the

7. This Part speaks interchangeably of early choice-of-law theory, the traditional approach to choice of law, the lex loci approach, and the First Restatement approach to conflicts. Any reference to the traditional conflicts theory is meant to refer to a model of conflicts that emphasizes vested rights and territoriality. 
states. As Joseph Beale explained, "[T]he power of a state is supreme within its own territory, [so] no other state can exercise power there. ... It follows generally that no statute has force to affect any person, thing, or act ... outside the territory of the state that passed it." ${ }^{\circ}$ The emphasis on territorial sovereignty present in traditional conflicts of law approaches gave rise to the general lex loci rule, indicating the "law of the place" of the last relevant act necessary to give rise to a legal right is the law that governs an action concerning that right. ${ }^{9}$

Indeed, according to the vested rights approach, the term "conflict of laws" is something of a misnomer. The traditional understanding is that the territorial law of the place where the legal right vested is totally sovereign. In theory, then, there should never be a "conflict" between two different laws - the laws of the territorial sovereign control legal rights to the exclusion of all other potential sources of law. The task of a choice-of-law theory, under the traditional view, was not to decide which law among several viable candidates should be given priority, but was rather to provide rules for determining where a given legal right came into being. ${ }^{10}$ Once the location of the vested right could be determined, the choice of what law to apply was easy. ${ }^{11}$

Formally, the First Restatement of Conflicts of Laws codified the vested rights approach. ${ }^{12}$ Take, for example, the First Restatement's approach to tort claims. The First Restatement directs that the substantive law of the place of the wrong applies in tort actions, where " $[\mathrm{t}]$ he place of wrong is in the state where the last event necessary to make an actor liable for an alleged tort takes place." 13 Similarly, issues in contract are generally governed by the law of the place where a formal contractual right accrued. Because the last act giving rise to a valid contract is usually acceptance, the law of the place of acceptance generally controls for questions of contract validity (i.e., whether a

8. 1 Joseph H. Beale, A Treatise On the Conflict of LaWs, § 61.1, at 311-12 (1935).

9. See Babcock v. Jackson, 191 N.E.2d 279, 281 (N.Y. 1963) (examining sources and explaining that the traditional lex loci approach "had its conceptual foundation in the vested rights doctrine, namely, that a right to recover for a foreign tort owes its creation to the law of the jurisdiction where the injury occurred and depends for its existence and extent solely on such law").

10. See generally Kermit Roosevelt III, The Myth of Choice of Law: Rethinking Conflicts, 97 MiCH. L. REV. 2448 (1999) [hereinafter Roosevelt III, The Myth of Choice of Law] (distinguishing between rules of "scope" and "conflicts rules" or rules of "priority" in conflicts of law).

11. Id. at 2455 (stating that the territorial approach, in the eyes of Joseph Beale, provides "a relatively easy answer to the question of what law governs a particular occurrence").

12. See generally ReStatement (FIRST) OF CONFLict of LAwS (AM. LAW InSt. 1934).

13. Id. $\S 377$. Because injury is usually the last act necessary to create a vested right in tort, the place of injury generally controls. 
contract arose and whether any such contract is valid). ${ }^{14}$ When, however, the contested issue in a case deals with a breach of contract, rather than contract validity, the First Restatement directs courts to look to the place of performance for the applicable legal standard. ${ }^{15}$

The territoriality concerns of the First Restatement are perhaps nowhere more prominent than in its approach to conflicts questions affecting property. The First Restatement provides that, "The original creation of property in a tangible thing is governed by the law of the state where the thing is at the time of the events which create the interests." 16 For real property, then, the law of the state where the land is will always control. For chattel, the law of the place where the chattel is at the time the right accrues controls. ${ }^{17}$

The strictly territorial logic of the First Restatement's vested rights approach to choice-of-law questions produces a conflicts system with a formally discernable task for judges: determine whether the party before the court has a vested legal right; then determine the place where the legal right at issue actually became enforceable; and then apply the law of that place. But the rule-based formality of the First Restatement approach sometimes led to questionable outcomes. ${ }^{18}$ When the "last act" necessary to give rise to a legal right took place in State B, but all of the precursor events took place in State A and the parties themselves were domiciliaries of State A, the formality of the First Restatement produced

14. See id. $\S 311 \mathrm{cmt}$. d ("[I]n determining the place of contracting, the forum ascertains the place in which, under the general law of Contracts, the principal event necessary to make a contract occurs.").

15. See id. $\S 358$ ("The duty for the performance of which a party to a contract is bound will be discharged by compliance with the law of the place of performance of the promise ...."). This principle becomes difficult to apply as the contract becomes more complex. For example, contracts involving commerce in multiple states or governing acquisition of assets spread across the country may involve performance in many different places under a single contract.

16. Id. $\S 211$.

17. See id. $\S \S 255-258$. Capacity to convey a chattel, the formalities required for conveyance, validity of a conveyance, and the nature of an interest resulting from conveyance are all determined by the law of the place where the chattel is at the time of the conveyance. Id.

18. The outcomes of conflicts-of-law cases under the First Restatement can be "questionable" in at least two ways. First, as used here, the First Restatement sometimes leads to results in tension with ordinary notions of which law ought to control a given sequence of events. That is, even when the First Restatement implies a result that is perfectly predictable, that result might nevertheless be questionable because it is contrary to expectations. In those circumstances, we can think of the First Restatement as introducing some error costs into the choice-of-law system, but perhaps those error costs are offset by lower decision costs associated with predictable rules. But a result under the First Restatement might be questionable because the First Restatement itself leaves room for judicial discretion. See infra notes 23-26 and accompanying text. In those cases, the rule-based approach of the First Restatement breaks down. The resulting outcome potentially imposes not only an error cost, but also decision costs resulting from exercises of judicial discretion and a lack of predictability. 
counterintuitive results. ${ }^{19}$

Such counterintuitive results of the First Restatement's territorial emphasis are not difficult to produce. ${ }^{20}$ But the First Restatement does not leave courts wholly without resources to avoid arbitrary or unfair outcomes. For one thing, the strict territorial rules of the First Restatement apply only for a given type of legal claim - tort is governed by the place of injury, contract by the place of contracting, and so on. If there is some flexibility in how a party characterizes a claim, then it is possible to find corresponding flexibility in which law will apply under the First Restatement. ${ }^{21}$

Other parts of the First Restatement also provide some potential relief from the seeming inexorability of the territorial approach. For example, the First Restatement included a public policy exception to a legal right "created in another state the enforcement of which is contrary

19. One case that illustrates this difficulty is Alabama Great Southern Railroad Co. v. Carroll, 11 So. 803 (Ala. 1892). There, an employee of the Alabama Great Southern Railroad Company, W.D. Carroll, was injured when a link between two railcars broke. Carroll was a citizen of Alabama, the railroad was an Alabama corporation, the employment contract between the two parties was negotiated and signed in Alabama, and the negligent inspection which missed the weakness in the link took place in Alabama. Id. at 803-04. But the railroad's line took it between Chattanooga, Tennessee, and Meridian, Mississippi, and the link actually broke and caused Carroll's injury while the train was in Mississippi. Id. at 804 . The choice-of-law issue was important to the case because an Alabama statute provided that employees could recover against their employers for injuries caused by the negligence of a fellow employee. Id. at 805 . In contrast, Mississippi still followed the common law "fellow servant" rule, which denied recovery for such injuries. Id. The Alabama Supreme Court applied Mississippi law, exemplifying the lex loci approach. The Court declared:

The only true doctrine is that each sovereignty, state or nation, has the exclusive power to finally determine and declare what act or omissions in the conduct of one to another... shall impose a liability in damages for the consequent injury, and the courts of no other sovereignty can impute a damnifying quality to an act or omission which afforded no cause of action where it transpired.

Id. at $808-09$.

20. In property, see Blackwell v. Lurie, 71 P.3d 509, 511-12 (N.M. Ct. App. 2003) (holding that a sketch book owned by Montana domiciliaries and on consignment to a gallery in New Mexico was owned as tenancy by the entirety property because the sketch book had been acquired in Missouri). In contract, see Burr v. Beckler, 106 N.E. 206, 209 (Ill. 1914) (holding that a married woman lacked capacity to contract under the law of coverture when she mailed her acceptance from Florida, which had coverture law, despite the woman being an Illinois citizen and the contract's concerning a transaction in Illinois secured by Illinois property).

21. See, e.g., Haumschild v. Cont'1 Cas. Co., 95 N.W.2d 814 (Wis. 1959). In Haumschild, a Wisconsin couple had been driving in California, where they were injured in a car accident. Id. at 814. California law provided for interspousal immunity so that a wife could not recover against her husband in tort, but Wisconsin had no such immunity. Id. at 815 . While the First Restatement would perhaps indicate that California's law should apply to a tort claim where California was the place of injury, the Wisconsin Supreme Court instead applied Wisconsin law regarding interspousal immunity. Id. at 820 . The Wisconsin court reasoned that the issue in the case was not actually one of tort law but instead one of family law, since the purpose of the immunity was "preventing family discord" rather than tort policy. Id. at 817-18. 
to the strong public policy of the forum." 22 In addition, the First Restatement provides that "[a]11 matters of procedure are governed by the law of the forum." 23 While the basic substance-versus-procedure distinction is familiar from the Erie context, it operates somewhat differently in the choice-of-law context. Rather than asking whether a given rule "really regulates procedure," 24 courts in conflicts cases ask whether the law in question is "a condition of the cause of action itself" or rather goes to the enforcement of a potentially vested right by a court rather than to the right's substance. ${ }^{25}$ The key, in other words, is whether the issue affects the vesting of a legal right or merely regulates the procedure by which that vested right is enforced in a particular court.

While this view is consistent with the vested rights approach at a conceptual level, it provides some leeway for judges to consider whether the law at issue is so tightly bound up with the existence of a vested right so as to count as substantive, or whether it deals instead with procedural enforcement. That leeway within the First Restatement-and courts' reliance on it to avoid difficult outcomes-foreshadows the eventual move away from the First Restatement to conflicts theories that embrace a more judgment-based test. ${ }^{26}$

\section{THE CHOICE-OF-LAW REVOLUTION}

Uniform adherence to the First Restatement in American courts was short lived, lasting only until about 1950 . Driven by dissatisfaction with the rigidity of the First Restatement approach and the view that characterization, public policy, and other sources of judicial flexibility were unsatisfactory mechanisms for introducing discretion, choice of law underwent what is commonly referred to as a revolution starting in the mid-twentieth century. ${ }^{27}$ Alternative approaches led judges to focus on

22. RESTATEMENT (FIRST) OF CONFLICT OF LAWS $§ 612$ (AM. LAW INST. 1934).

23. Id. $\S 585$.

24. See Shady Grove Orthopedic Assocs., P.A. v. Allstate Ins. Co., 559 U.S. 393, 410 (plurality opinion) (quoting Sibbach v. Wilson \& Co., 312 U.S. 1, 13-14 (1941)).

25. RESTATEMENT (FIRST) OF CONFLICT OF LAWS $\S 595 \mathrm{cmt}$. a.

26. For one of the earliest critiques of the First Restatement cataloging judges' use of these socalled escape devices in the theory, see Walter Wheeler Cook, The Logical and Legal Bases of the Conflict of Laws, 33 YALE L.J. 457 (1924). Professor Walter Wheeler Cook's argument utilized a distinctively legal realist approach. He rejected the appeal of an a priori theory of conflicts and instead sought to derive rules for conflicts-of-law cases by observing and categorizing judicial behavior. Id. at 460. That exercise led Cook to conclude that judges applied the First Restatement inconsistently and to question whether any system of conflicts could achieve the algorithmic predictability to which the First Restatement aspired. Id. at 475-79.

27. See Perry Dane, Vested Rights, 'Vestedness,' and Choice of Law, 96 YALE L.J. 1191, 1196- 
the "contacts" that states had to particular disputes, ${ }^{28}$ the "interest" that a particular state had in seeing its law applied to resolve a given case, ${ }^{29}$ or the "superiority" of a particular legal rule after a judicial evaluation of the candidate laws that might apply to a case to determine which was "the better rule of law." 30 This Part begins by introducing, in broad strokes, the substance of some of the post-First Restatement conflicts approaches. That narrative goes all the way to the present, as there currently exists a Draft Restatement (Third) of Conflict of Laws that seeks to build on the lessons learned during the decades since the choiceof-law revolution. ${ }^{31}$

Next, this Part discusses an oft-forgotten aspect of the original discussion surrounding the move away from strict territoriality in choice of law: procedural and forum-based considerations. The choice-of-law revolution sought to restore some power to judges to deal pragmatically with choice-of-law issues rather than remaining bound by the rigid territoriality of the First Restatement. But in introducing that flexibility, scholars advocating for new choice-of-law theories recognized that state courts might be imperfect fora for administration of a system introducing more judicial discretion. The concern was that state court judges might use their discretion to decide choice-of-law issues reflexively in favor of the law of the forum. As such, early leaders of the choice-of-law revolution proposed that federal courts, rather than state courts, should make choice-of-law determinations. The final Section of this Part develops and evaluates this underemphasized aspect of the revolution's

1203 (1987).

28. See, e.g., Auten v. Auten, 124 N.E.2d 99, 101-02 (N.Y. 1954) ("Turning to the case before us, examination of the respective contacts with New York and England compels the conclusion that it is English law which must be applied to determine the impact and effect to be given the wife's institution of the separation suit."). See also Restatement (SECOND) OF CONFLict OF LAWs $\S$ 6(2)(b)-(c) (AM. LAW INST. 1971) (incorporating interest analysis).

29. See, e.g., Bernkrant v. Fowler, 360 P.2d 906, 910 (Cal. 1961) ("“W]e can give effect to the common law policy of both states to enforce lawful contracts and sustain Nevada's interest in protecting its residents and their reasonable expectations growing out of a transaction substantially related to that state without subordinating any legitimate interest of this state.").

30. See Robert A. Leflar, Conflicts Law: More on Choice-Influencing Considerations, 54 CAL. L. REV. 1584, 1587-88 (1966). Note that Professor Leflar's original scholarship sought to be descriptive rather than normative- he noticed that courts were sometimes influenced by their judgment of which law in a conflicts case led to better results. Courts subsequently applied his theory normatively, using their determination of which was the "better law" in a conflicts case as a justification for application of that law in a particular dispute. See, e.g., Milkovich v. Saari, 203 N.W.2d 408, 417 (Minn. 1973) ("In that posture, we are concerned that our courts not be called upon to determine issues under rules which, however, accepted they may be in other states, are inconsistent with our own concept of fairness and equity.").

31. See Restatement (Third) of Conflict of Laws (Am. Law Inst., Council Draft No. 2, Sept. 12, 2017). 
intellectual foundation.

\section{A. The Early Break}

The judicial origins of the choice-of-law revolution trace back to a series of New York state court decisions in the 1950s. ${ }^{32}$ Beginning with two cases involving family law support obligations, ${ }^{33}$ New York courts showed some willingness to set aside the First Restatement rule that the place of contracting should govern a separation agreement. In Auten $v$. Auten, the New York Court of Appeals described a process of assessing the "place with the most significant contacts" to determine which law to apply to a dispute. ${ }^{34}$ The court's "most significant contacts" formulation is important because it employs a test wholly foreign to the First Restatement's territorial approach. ${ }^{35}$ While other courts would reach similar practical outcomes using characterization or other techniques internal to the First Restatement approach, ${ }^{36}$ the Auten court did not even purport to apply the First Restatement. ${ }^{37}$

New York courts continued to break with the First Restatement in the following years in a series of cases involving car accidents. A recurring question during that time was whether New York courts would enforce so-called guest statutes, which were laws that prevented a passenger from suing a host-driver in tort for injuries sustained in car accidents. ${ }^{38}$ New York had no such statute, but cases arose in which its courts had to determine whether guest statutes should apply to accidents that occurred in states or countries where the statutes were in force when the accident involved New York parties. ${ }^{39}$

In Babcock v. Jackson, New York courts first confronted the question when a car accident in Ontario, Canada, injured New York citizens. $^{40}$ Ontario had a guest statute, which, if applied, would have barred the New York passengers from recovering against the New York

32. See generally Willis L.M. Reese, Chief Judge Fuld and Choice of Law, 71 COLUM. L. Rev. 548 (1971) [hereinafter Reese, Chief Judge Fuld].

33. Auten v. Auten, 124 N.E.2d 99, 103-04 (N.Y. 1954); Haag v. Barnes, 175 N.E.2d 441, 444 (N.Y. 1961).

34. Auten, 124 N.E.2d at 103.

35. Id. at 101-02 (discussing the First Restatement approach before applying an analysis about significant contacts).

36. See, e.g., Haumschild v. Cont'l Cas. Co., 95 N.W.2d 814, 820 (Wis. 1959).

37. Auten, 124 N.E.2d at 103 . The court did, however, note that it would reach the same outcome applying either approach. Id.

38. See, e.g., Babcock v. Jackson, 191 N.E.2d 279 (N.Y. 1963).

39. See, e.g., id. at 280.

40. Id. 
driver. ${ }^{41}$ While the place of injury was Canada, both parties were New York residents, where the vehicle at issue was also registered and insured. ${ }^{42}$ Setting aside the "traditional choice of law rule ... that the substantive rights and liabilities arising out of a tortious occurrence are determinable by the law of the place of the tort," of Appeals instead centered its analysis on "contacts." ${ }^{44}$ The court explained, "Comparison of the relative 'contacts' and 'interests' of New York and Ontario in this litigation, vis-a-vis the issue here presented, makes it clear that the concern of New York is unquestionably the greater and more direct and that the interest of Ontario is at best minimal." 45 The court dismissed Ontario's status as the place of injury as a "purely adventitious circumstance" that should not outweigh all of the other ties to New York present in the facts before the court. ${ }^{46}$

The New York Court of Appeals then announced a more general statement of the state's approach to guest-statute cases in Neumeier $v$. Kuehner. ${ }^{47}$ Again, the court emphasized not territoriality but rather the relative interests of the states involved in the case and the purposes behind each state's policy. ${ }^{48}$ For example, the court considered the

41. Id.

42. Id. at 284 .

43. Id. at 281 (citations omitted).

44. Id. at $283-84$.

45. Id. at 284. Perhaps one can resist the assertion that it is indeed "unquestionable" that New York had the more direct interest in the accident. While the residency of the parties, the insurance, and the registration of the vehicle pointed toward New York, Ontario does have an interest in how the law shapes drivers' behavior on Ontario roads. But New York courts considered guest statutes to be "loss-allocating" rather than "conduct-regulating" rules, meaning that the primary effect of the rule is to determine which party will bear a loss rather than to identify particular acts as wrongful. While a state does have a strong interest in applying a rule aimed at regulating conduct within its borders, it is thought that parties' common domicile provides an overwhelming interest in favor of applying a loss-allocating rule of that domicile. For more on this distinction, see Wendy Collins Perdue, A Reexamination of the Distinction Between "Loss-Allocating" and "Conduct-Regulating Rules," 60 LA. L. REV. 1251, 1251-52 (2000).

46. Babcock, 191 N.E.2d at 284. The Court of Appeals of New York reaffirmed the reasoning of Babcock in Tooker v. Lopez, which again involved a car accident between New York citizens that occurred in Michigan, a state with a guest statute. 249 N.E.2d 394, 395 (N.Y. 1969). The common citizenship of the parties involved in the accident and suit was enough to overcome the traditional application of the law of the place of injury, with the court again emphasizing New York's superior interest in the case. Id. at 398 ("[I]t is clear that New York has the only real interest in whether recovery should be granted and that the application of Michigan law 'would defeat a legitimate interest of the forum State without serving a legitimate interest of any other State." (quoting Intercontinental Planning, Ltd. v. Daystrom, Inc., 248 N.E.2d 576, 584 (1969))).

47. 286 N.E.2d 454, 457-58 (N.Y. 1972).

48. See id. ("[I]n Babcock v. Jackson, ... we were willing to sacrifice the certainty provided by the old rule for the more just, fair and practical result that may best be achieved by giving controlling effect to the law of the jurisdiction which has the greatest concern with, or interest in, the specific issue raised in the litigation." (citation omitted)). 
purpose of the guest statute to be either "to protect Ontario defendants and their insurers against collusive claims" drivers against ungrateful guests." 50 But, the court explained, "New York has a deep interest in protecting its own residents, injured in a foreign state, against unfair or anachronistic statutes of that state." ${ }^{, 51}$

From these principles, the Neumeier court derived three general rules for determining whether a foreign guest statute would apply to bar recovery by a New York plaintiff. First, if the domicile of the passenger and driver is the same, then the law of that state should control. ${ }^{52}$ Second, if the driver's conduct occurred in her home state and that state would protect the driver from liability, then the driver's home-state law applies. ${ }^{53}$ Similarly, if the accident occurred in the passenger's home state and the law of that state allows recovery, then the law of the passenger's state applies. ${ }^{54}$ In other words, the court reasoned that the law of the state where the injury occurred should apply if that law benefits a party domiciled in that state in cases where the citizenship of the parties differs. ${ }^{55}$ Finally, where the passenger and driver are domiciled in different states but the law of the state of injury does not favor a citizen-party of that state, the court defaults to the law of the place of injury but can consider other factors. ${ }^{56}$

\section{B. Scholarly Contributions: Interest Analysis}

The "Neumeier Rules" map well onto a more general conflicts approach, interest analysis - an approach championed by Professor Brainerd Currie and developed in response to dissatisfaction with the territorial emphasis of the First Restatement. Writing around the same time as the New York Court of Appeals broke from the traditional approach, Currie advocated for a conflicts system that "inquire[s] into

49. Id. at 455 (citing Babcock, 191 N.E.2d at 283-84).

50. Id. (quoting Reese, Chief Judge Fuld, supra note 32, at 558).

51. Id. at 456 .

52. Id. at 457 .

53. Id. at $457-58$.

54. Id.

55. Id. In this way, the New York Court of Appeals traded one form of inconsistency under the First Restatement (which gives different outcomes depending on where the accident occurred, independent of the citizenship of the driver) for another under the Neumeier rules (which give different outcomes depending on the location of the accident and the citizenship of the driver). While both rules are internally consistent, the question of which rules provide more predictable and satisfying outcomes likely depends on one's prior assumptions about the desirability of territorial sovereignty as opposed to citizenship-based interests.

56. Id. at 458 . 
the policies expressed in the respective laws, and into the circumstances in which it is reasonable for the respective states to assert an interest in the application of those policies." 57 In Currie's view, choice-of-law decisions should proceed not as an algorithmic process but rather as an exercise in statutory interpretation. ${ }^{58}$ As Currie explained, interest analysis "is essentially the familiar [process] of construction or interpretation. "J9 "Just as we determine by that process how a statute applies in time, and how it applies to marginal domestic situations, so we may determine how it should be applied to cases involving foreign elements in order to effectuate the legislative purpose."

Interest analysis, in its original formulation, operates from the premise that a state's laws are intended to apply principally to situations in which the laws benefit domiciliaries of that state. ${ }^{61}$ The Ontario guest statute, for example, should be interpreted to protect Ontario citizens from being potentially liable to their guests; but the statute should not also be read to extend the same interest in protection to New Yorkers, even when involved in a crash on Ontario roads. Interest analysis thus leads to straightforward results in situations like those described in the second Neumeier rule: situations in which there is a statute at issue that is designed to protect one of the parties in the litigation. ${ }^{62}$ These situations are, in Currie's terminology, "false conflicts"-what on the surface appears to be a conflict of laws between two states actually dissolves when courts consider whether the states' purposes for enacting the statute apply in the instant case. ${ }^{63}$

More difficult for interest analysis are situations involving either "true conflicts" or "unprovided-for cases." 64 In the former, both states" laws can be reasonably interpreted to apply to a particular controversy. ${ }^{65}$

57. Brainerd Currie, Comments on Babcock v. Jackson, A Recent Development in Conflict of Laws, 63 Colum. L. Rev. 1233, 1242 (1963) [hereinafter Currie, Comments on Babcock v. Jackson].

58. See Brainerd Currie, Notes on Methods and Objectives in the Conflict of Laws, 1959 DuKE L.J. 171, 178 (1959) [hereinafter Currie, Notes on Methods and Objectives]. This aspect of Currie's theory has been an emphasis of the Draft Third Restatement's approach.

59. Id.

60. Id.

61. See generally John Hart Ely, Choice of Law and the State's Interest in Protecting Its Own, 23 WM. \& MARY L. REV. 173 (1981).

62. Neumeier v. Kuehner, 286 N.E.2d 454, 457 (N.Y. 1972).

63. William M. Richman, Diagramming Conflicts: A Graphic Understanding on Interest Analysis, 43 Онго Sт. L.J. 317, 318-19 (1982) (explaining that a false conflict occurs when "only one state's policy is advanced by application of its law").

64. Id. at 320-23.

65. Id. at 320 . 
In one famous example, an Oregon resident entered into a business contract in California with a California citizen. ${ }^{66}$ Unbeknownst to the California party, the Oregon citizen had been declared a spendthrift under Oregon law, a protection not known to California law. ${ }^{67}$ Thus, California had an interest in the case in enforcing contracts entered into in California and in providing recovery for its citizen, but Oregon also had an interest under its own law of enforcing spendthrift determinations and protecting its citizen. ${ }^{68}$ Cases such as these are said to present "true conflicts" because a straightforward interpretation of each state's law shows that it was intended to apply to the case before the court. ${ }^{69}$ In such cases, Currie advocated for a careful "reconsideration" of the interests underlying each statute and then, if the true conflict persisted, default application of the law of the forum. ${ }^{70}$

The difficulty of the "unprovided-for case" is similar to, though the inverse of, the true conflict case. In an unprovided-for case, neither state's law seems to apply to the dispute. ${ }^{71}$ Consider a permutation of the guest statute cases in which an Ontario passenger is injured by a New York driver. $^{72}$ Application of the Ontario statute would serve to bar recovery benefiting an Ontario citizen, an outcome in which Ontario is presumably not interested. ${ }^{73}$ Similarly, application of New York law would impose liability on the driver, which might be thought contrary to the State of New York's interests. In such cases, Currie again advocated

66. Lilienthal v. Kaufman, 395 P.2d 543, 543-44 (Or. 1964) (en banc).

67. Id.

68. See id. at 546-48.

69. See Richman, supra note 63, at 320-21 (discussing and diagramming the true conflict dilemma in Lilienthal).

70. Currie, Comments on Babcock v. Jackson, supra note 57, at 1242-43.

71. Richman, supra note 63 , at 322 .

72. The location of the accident is not significant for the purposes of the hypothetical because interest analysis is not territorially focused.

73. While the presumption that states are interested only in or at least primarily in the application of their laws to promote the interests of their own citizens does cohere with the interest analysis approach, it is not without controversy. For example, Professor Douglas Laycock has argued that the Fourteenth Amendment's Privileges and Immunities Clause should be read to make a state's exclusive preference for its own citizens unconstitutional. See Douglas Laycock, Equal Citizens of Equal and Territorial States: The Constitutional Foundations of Choice of Law, 92 COLUM. L. REV. 249, 264 (1992) ("Any discrimination against visiting citizens of sister states harms the victim and strikes a small blow against national unity. Discrimination against citizens of sister states, justified only by a preference for locals or a view that the state has no interest in protecting outsiders, undermines our tendency to think of ourselves as a single people and leaves the victims with a legitimate sense of raw injustice."). Resolution of the constitutional worry is unnecessary for this Article, but procedural mechanisms that place the determination of when a state is "interested" in application of its law into the hands of a more neutral federal judge may help to ameliorate some of the discriminatory concerns that Laycock raises. 
for a default application of forum law. ${ }^{74}$

Substantively, Currie's interest analysis scholarship has been influential. California and the District of Columbia explicitly follow interest analysis to resolve conflicts of law in tort cases, ${ }^{75}$ and the Second Restatement of Conflicts of Law incorporates state interests as one of the general principles guiding choice-of-law decisions. ${ }^{76}$ In addition, the willingness of interest analysis to elevate state interests over rule-based territoriality paved the way for other standards-based methods of conflicts resolution such as comparative impairment and better law.

During the period of flux ushered in by the scholarly break with territoriality in choice of law, the American Law Institute began work on the Restatement (Second) of Conflicts of Law. ${ }^{77}$ The Second Restatement was eventually published in 1971, but, conscious of the rapid rate of doctrinal evolution in choice of law at the time, the Second Restatement was positioned as a "transitional work." 78 Perhaps unsurprisingly then, the Second Restatement gives few definite rules for choice-of-law problems. Instead, the centerpiece of the Second Restatement is section 6 , which provides a laundry list of factors that judges ought to consider when deciding which law has the "most significant relationship" to a given dispute. ${ }^{79}$ Section 6 , subsection 2 instructs courts to consider:

(a) the needs of the interstate and international systems,

(b) the relevant policies of the forum,

(c) the relevant policies of other interested states and the relative interests of those states in the determination of the particular issue,

74. See Brainerd Currie, Survival of Actions: Adjudication Versus Automation in the Conflict of Laws, 10 STAN. L. REV. 205, 229-30 (1958) (noting that frustration of one state's interest is inevitable in such cases). But see Larry Kramer, The Myth of the "Unprovided-for" Case, 75 VA. L. REV. 1045, 1051-52 (1989) (arguing that unprovided for cases should simply be dismissed as failing to state a claim under any potentially applicable law).

75. See Symeon C. Symeonides, Choice of Law in the American Courts in 2017: Thirty-First Annual Survey, 66 AM. J. CoMP. L. 1, 61 (2018) (charting choice-of-law methods for all fifty states, Washington D.C., and Puerto Rico).

76. See Restatement (SeCOND) OF Conflict of LaWs § 6(2)(b)-(c) (Am. LaW Inst. 1971) (" $[T]$ he factors relevant to the choice of the applicable rule of law include ... the relevant policies of the forum, [and] ... the relevant policies of other interested states and the relative interests of those states in the determination of the particular issue ....").

77. Willis L.M. Reese, Conflict of Laws and the Second Restatement, 28 L. \& ConTEMP. PROBS. 679, 679-80 (1963).

78. Willis L.M. Reese, The Second Restatement of Conflict of Laws Revisited, 34 MERCER L. REV. 501, 519 (1983).

79. See Restatement (SeCond) of Conflict of LaWs $\S 6 \mathrm{cmt}$. c (Am. LaW InSt. 1971). 
(d) the protection of justified expectations,

(e) the basic policies underlying the particular field of law,

(f) certainty, predictability and uniformity of result, and

(g) ease in the determination and application of the law to be applied. ${ }^{80}$

In contrast to the algorithmic processes of the First Restatement approach, the Second Restatement embraces more of an "all-thingsconsidered" test. That test provides a large degree of flexibility for judges seeking to avoid the counterintuitive results of application of the First Restatement to some cases, but it also creates a more substantial role for judges sifting among the various factors within section 6 .

Despite (or, more cynically, perhaps because of) the lack of firm answers provided in the Second Restatement approach, it has proven very popular among states. ${ }^{81}$ For all its popularity, however, the Second Restatement has done little to settle many of the core issues in conflicts law that have persisted since the very beginning of the choice-of-law revolution.

\section{The Draft Restatement (Third) of Conflicts of Law}

With the Second Restatement having caught on in a majority of the states but with significant divergence in states' choice-of-law methodologies still present, the American Law Institute has commissioned work on a Third Restatement of Conflicts of Law. That document, currently in draft form, has been described by its Reporter, Professor Kermit Roosevelt III, as an attempt "to survey the practice of courts using the Restatement (Second) and other modern approaches; to consider codifications in the United States and elsewhere; and to determine when practice converges sufficiently to allow the formulation of appropriately narrow and policy-sensitive rules." 82 This, Roosevelt suggests, is the natural and intended progression from the Second Restatement, which was originally intended as "more of a means of

80. $I d . \S 6(2)$.

81. The best available data indicate that the Second Restatement is used in twenty-five of fiftytwo surveyed jurisdictions. See Symeon C. Symeonides, Choice of Law in the American Courts in 2018: Thirty-Second Annual Survey, 67 AM. J. Comp. L. 1, 35 (2019) [hereinafter Symeonides, Choice of Law in 2018].

82. Kermit Roosevelt III \& Bethan R. Jones, The Draft Restatement (Third) of Conflict of Laws: A Response to Brilmayer \& Listwa, 128 YALE L.J. F. 293, 295 (2018). 
collecting data that would allow future reporters to write better rules." 83

Much of the substantive contribution of the Draft Restatement centers on a reframing of conflicts questions around a two-step inquiry: first, determining the scope of state laws to determine whether any are applicable to the dispute at hand and, second, giving priority to one law if more than one applies after step one. ${ }^{84}$ This "scope and priority" approach has been a feature of Roosevelt's conflicts scholarship. ${ }^{85} \mathrm{He}$ summarizes the approach as involving two distinct questions: "scope questions are about whether a given law creates a right or not, conflicts questions are about when one right prevails over another." ${ }^{\prime 86}$

Some of the academic reaction to the project of the Third Restatement involves a wary skepticism. ${ }^{87}$ For example, Professor Lea Brilmayer and Daniel Listwa criticize the Draft Restatement for what they characterize as a contradiction inherent in its two-step structure, which they argue purports to base its methodology in statutory interpretation while lacking the "institutional capacity" to "ground[] a persuasive argument from statutory interpretation." 88

In response, Roosevelt and Bethan R. Jones defend the Draft Restatement against this criticism on substantive grounds, arguing that the Draft Restatement's rules for interpreting the scope of state statutes are sound based on a survey of known judicial decisions and, what's more, bear only on the first, scope-defining step of the Draft Restatement's conflicts inquiry. ${ }^{89}$ The Draft Restatement has separate mechanisms for determining priority among multiple potentially applicable statutes. ${ }^{90}$ Resolution of these sorts of substantive disagreements over the Third Restatement is not the goal of this Article.

83. Id. at 294-95.

84. Kermit Roosevelt III, Choice of Law in Federal Courts: From Erie and Klaxon to CAFA and Shady Grove, 106 N.W. L. REV. 1, 11 (2012) [hereinafter Roosevelt III, Choice of Law in Federal Courts].

85. See, e.g., Roosevelt III, The Myth of Choice of Law, supra note 10, at 2520; Roosevelt III, Choice of Law in Federal Courts, supra note 84, at 26.

86. Roosevelt III, The Myth of Choice of Law, supra note 10, at 2520.

87. See, e.g., Friedrich K. Juenger, A Third Conflicts Restatement?, 75 IND. L.J. 403, 403 (2000) ("How does one restate gibberish?"); Russell J. Weintraub, The Restatement Third of Conflict of Laws: An Idea Whose Time Has Not Come, 75 IND. L.J. 679, 679 (2000) ("[I]t is not time to embark on the drafting of a third restatement."); Lea Brilmayer \& Daniel B. Listwa, Continuity and Change in the Draft Restatement (Third) of Conflict of Laws: One Step Forward and Two Steps Back?, 128 YALE L.J. F. 266, 267 (2018) ("The changes [to the Draft] are significant, but so are the continuities. Unfortunately, despite what its drafters would have us believe, the changes and continuities are not compatible.").

88. See Brilmayer \& Listwa, supra note 87 , at 276.

89. See generally Roosevelt III \& Jones, supra note 82.

90. See id. at 308. 
Rather, I note them in order to establish where the discussion surrounding the Draft Restatement is currently focused and as an indication of where that focus is likely to remain.

Though the debate about the wisdom and presentation of the twostep approach to conflicts questions is important, it misses an opportunity to rethink choice of law from a different angle. Specifically, it fails to critically evaluate not just the rules of decision for choice-of-law cases but also the identity of the decision-makers themselves. Indeed, while Roosevelt has positioned the Third Restatement as fulfilling the vision of the Second Restatement, a vision of which "[a]cademics lost sight," debates about the substantive merits of the Third Restatement's two-step model have themselves lost sight of an important procedural debate that was alive and well during the period surrounding the Second Restatement's passage. That debate centered on whether choice-of-law questions, and the concerns for state-based interests and policies that attend them, are best answered by state court judges. The next Section summarizes that debate, which this Article suggests should once again become part of the discussion surrounding the Restatement's efforts to summarize the current state of conflicts law and to chart a course for the future.

\section{The Forgotten Procedural Debate}

The choice-of-law revolution succeeded in convincing many states to drop the territorial vested rights approach and to consider instead states' interests in their policies and domiciliaries. But alongside those calls for a broader conception of when a particular state's law might apply to a given issue, was a deep skepticism over whether the states themselves should implement that broadened conception. For example, Currie's early writings on interest analysis include not only a call for an approach to conflicts of law driven by statutory interpretation and state interest, but also an express desire for an increased federal role in answering conflicts questions. In 1954, Currie considered how the recently enacted Change of Venue provision of 28 U.S.C. $\S$ 1404(a) would interact with choice of law. ${ }^{92}$ In particular, Currie considered whether a case transferred for the convenience of the parties to a new venue should apply the conflict-oflaws rules of the new or old venue in the subsequent litigation. ${ }^{93}$ One

91. Id. at 295 .

92. See Brainerd Currie, Change of Venue and the Conflict of Laws, 22 U. CHI. L. REV. 405 (1954) [hereinafter Currie, Change of Venue].

93. Id. at 407 . 
worry was that transfer of a case within the federal system might provide litigants with a tool to evade the choice-of-law results of the original forum state, thus endangering the vertical federal state uniformity that Erie Railroad Co. v. Tompkins ${ }^{94}$ sought to enforce. ${ }^{95}$ Currie suggested that perhaps we ought to "concede to the federal courts power to make an independent choice of law in conjunction with transfer." 96 Indeed, he also suggested that the principle should be extended generally to allow "the federal courts [to] be freed of [the] compulsion to follow state rules of conflict of laws." 97 In Currie's view, "the implications of Section 1404(a) provide an opportunity for gradual development," and that opportunity might lead to a federally uniform system of choice of law as developing in federal courts and "more enlightened rules for choice of law." 98 Considering the choice-of-law problem in relation to change of venue led Currie to promote the virtues of federal uniformity in conflicts theory.

Five years later, Currie published a retraction of his earlier view, saying, "This position assumes that it is possible to develop a rational system of conflict of laws in the abstract, independently of the policies and interests of the governments legitimately concerned .... This, I am now convinced, is an impossibility." 99 But Currie's retraction has more to do with the merits of a federally developed conflicts system as opposed to a state-developed one. That is, Currie originally thought that perhaps the federal courts could develop a separate and free-standing conflicts regime that would be more uniform and better-reasoned than the assorted systems in place in the states. That sort of independent federal common law of conflicts does seem to run afoul of the logic of Erie because it would erode vertical uniformity between state and federal courts. ${ }^{100}$ In addition, an independent federal common law of conflicts would conflict with the Rules of Decision Act, which requires application of state substantive law in diversity cases (where Congress does not provide otherwise). ${ }^{101}$

But the general idea that there might be advantages to resolution of

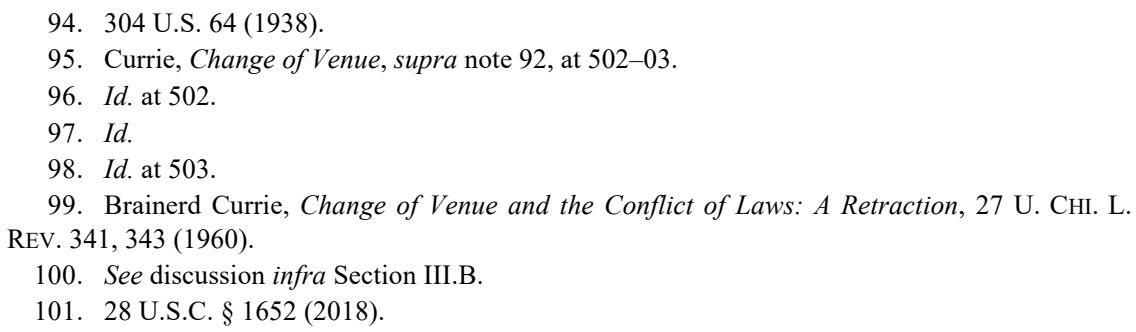


conflicts issues at the federal level rather than state level was picked up by Currie's contemporaries. Most notably, Professor William Baxter proposed that conflicts questions ought to be resolved in federal rather than state courts - not because federal courts could develop better substantive rules, but because federal courts were the institutions that could more credibly be trusted with the careful analysis of conflicting state interests that Currie's theory required. ${ }^{102}$

Baxter introduced the idea that, independent of method, conflicts questions are best resolved by federal rather than state institutions. ${ }^{103}$ First, Baxter reasoned that state courts are best seen as implementers of state policy, an extension of the state's substantive legal aims. ${ }^{104}$ As Baxter seems to have conceived of the division of governmental power, legislators enshrine state policy in law and the courts implement that policy by upholding the laws. In that view of the role of state courts, leaving resolution of conflicts questions in the hands of state courts creates problems. As Baxter explained:

Currie, throughout his recent writings, has assumed that state courts would be the tribunals with ultimate responsibility for [choice of law adjudication].... That is a disquieting prospect. The courts of each state are active participants in the formulation and implementation of local policies. To place in their hands extensive responsibility for deciding when those policies will yield to and when they will prevail over the competing policies of sister states seems unsound.... Responsibility for allocating spheres of legal control among member states of a federal system cannot sensibly be placed elsewhere than with the federal government. ${ }^{105}$

Underlying Baxter's concern is a certain sort of skepticism about the judgment required in any conflicts regime. Part of the point of the

102. William F. Baxter, Choice of Law and the Federal System, 16 Stan. L. REv. 1, 22-23 (1963).

103. Id.

104. Id. at 23 .

105. Id. at 22-23. Notably, the Court of Appeals for the D.C. Circuit expressed similar concerns almost twenty years later in the context of international conflicts of law when deciding Laker Airways Ltd. v. Sabena, Belgian World Airlines, 731 F.2d 909 (1984). The issue in the case was whether the antitrust law of the United States or of Great Britain should apply to a suit by Laker Airways alleging that predatory pricing had driven Laker out of business. Id. at 917-18. The D.C. Circuit acknowledged that it faced a choice between "fundamentally opposed national policies toward prohibition of anticompetitive business activity." Id. at 945 . The court, however, rejected the notion that it should balance the interests of each country in the application of its law to the dispute, reasoning that "this approach is unsuitable when courts are forced to choose between a domestic law which is designed to protect domestic interests, and a foreign law .... [T] here are substantial limitations on the court's ability to conduct a neutral balancing of the competing interests." Id. at 948 . 
revolution in choice of law was to do away with a system (the First Restatement) that purported to provide algorithmic solutions to choiceof-law problems. ${ }^{106}$ But, as previously described, courts found ways to influence the workings of the First Restatement system: for example, through characterization, public policy exceptions, or the substanceversus-procedure distinction. ${ }^{107}$ In response, governmental interest analysis proposed not territorial rules, but an exercise in statutory interpretation, determining whether particular statutes were best read to apply to a given set of circumstances. ${ }^{108}$ Baxter points out that this process, too, involves room for manipulation and the exercise of judgment within a zone of permissible discretion. ${ }^{109}$ Indeed, that discretion was thought to be a feature of the system rather than a bug. ${ }^{110}$ But if that is true, then one might worry about tasking state courts with that interpretation. Specifically, one might worry that state court judges are inclined to read the statutes of their own states expansively while reading other states' statutes narrowly, or that judges might "weigh" the interests in question ${ }^{111}$ and naturally be inclined to consider their own state's interests to be more significant. Because no rule is self-applying, any system of conflicts will involve some amount of human judgment, but the more such judgment becomes a feature of a particular conflicts approach, the more one might worry about the use of state rather than federal courts for resolution of conflicts issues.

Complementary to concerns of bias toward home-state policies, Baxter feared that a state-by-state approach to conflict-of-laws problems is inconsistent with American federalism. ${ }^{112}$ As Baxter described, a

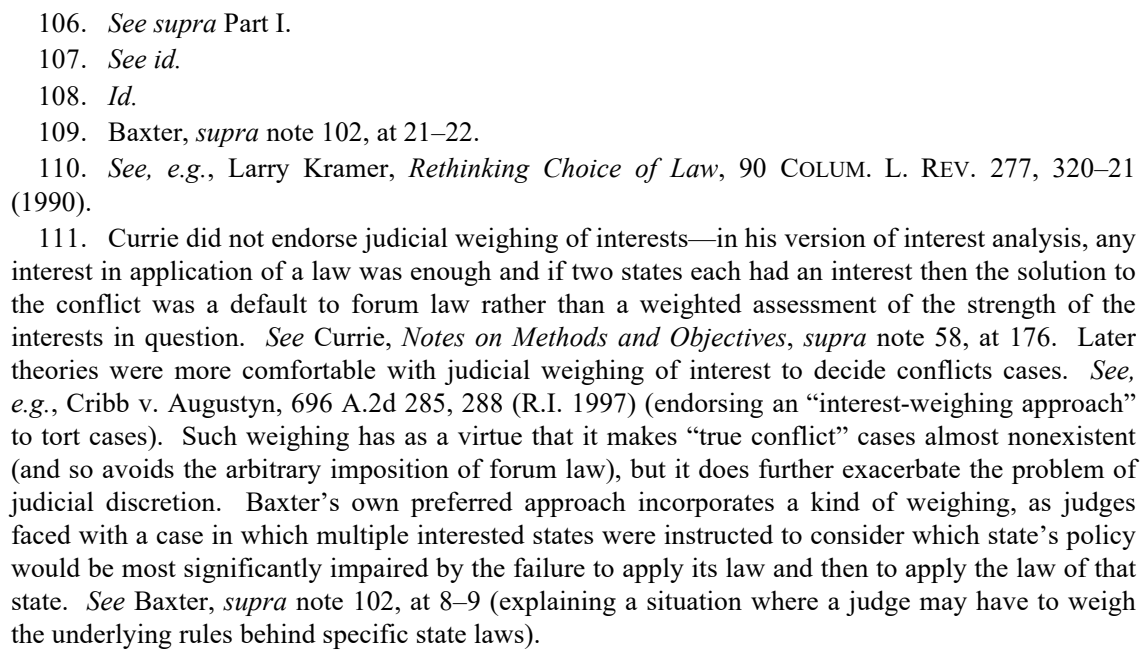

111. Currie did not endorse judicial weighing of interests - in his version of interest analysis, any interest in application of a law was enough and if two states each had an interest then the solution to the conflict was a default to forum law rather than a weighted assessment of the strength of the interests in question. See Currie, Notes on Methods and Objectives, supra note 58, at 176. Later theories were more comfortable with judicial weighing of interest to decide conflicts cases. See, e.g., Cribb v. Augustyn, 696 A.2d 285, 288 (R.I. 1997) (endorsing an "interest-weighing approach" to tort cases). Such weighing has as a virtue that it makes "true conflict" cases almost nonexistent (and so avoids the arbitrary imposition of forum law), but it does further exacerbate the problem of judicial discretion. Baxter's own preferred approach incorporates a kind of weighing, as judges faced with a case in which multiple interested states were instructed to consider which state's policy would be most significantly impaired by the failure to apply its law and then to apply the law of that state. See Baxter, supra note 102, at 8-9 (explaining a situation where a judge may have to weigh the underlying rules behind specific state laws).

112. Baxter, supra note 102, at 23-25. 
federal system does not involve unquestioning deference to local policy, but rather a give and take between local autonomy and more unified national supervision. ${ }^{113}$ States must be given some freedom to craft local solutions to problems, and federalism requires that those solutions not be frustrated by national encroachment. But, equally important, encroachment by other states can just as easily frustrate the policy aims of a particular state. Baxter worried that a state-by-state conflicts approach traded the risk of federal encroachment on state policy goals for the certainty of encroachment on those goals by sister states:

The justification for the cumbersome political arrangement known as federation is that certain problems are best handled at the local level because varying local circumstances may call for varying solutions and because varying attempts may reveal better solutions. The premise of state autonomy as to local problems presupposes that each state will be permitted to effectuate, to the extent consistent with the identical right of every other state, the policies it adopts. Those policies are as susceptible to frustration by sister states as by the central government. 114

Baxter's analysis identifies two virtues of the federal system: responsiveness to local concerns and the benefits of experimentation. ${ }^{115}$ Regarding the first justification, a conflicts system that leaves states free to judge their own interests in a dispute to be more significant than the interests of their sister states necessarily restricts the ability of sister states to exercise local control. ${ }^{116}$ Rather than promoting the development of policy best suited to the needs of a particular locality, those rules simply encourage parties to file lawsuits in states with favorable law. ${ }^{117}$

In terms of the second justification, it is not clear that a state-by-state approach to conflicts does much to encourage experimentation and innovation. True, different states have different conflicts systems, but the current approach encourages states to adopt systems that maximally

113. Id. at 25

114. $I d$. at 24 . In a variety of ways, the law restraining states from extraterritorial application of their laws is underdeveloped, but in the context of the Commerce Clause, the United States Supreme Court has recognized that states acting locally can easily frustrate sister state or federal schemes of commerce regulation. See, e.g., Pike v. Bruce Church, 397 U.S. 137, 142 (1970) (explaining that facially neutral state statutes violate the Commerce Clause if "the burden imposed on [interstate] commerce is clearly excessive in relation to the putative local benefits" (citing Huron Portland Cement Co. v. City of Detroit, 362 U.S. 440, 443 (1960))).

115. See Baxter, supra note 102, at 22-25.

116. See id. at $19-20$.

117. Id. (expressing concern for forum selection under Currie's state-by-state approach). 
promote their own interests, rather than encouraging development of a better system along other dimensions (coherence with litigants' expectations, ease of administration, etc.). ${ }^{118}$ In sum, the general federalism justifications for pushing decision making to the local level do not seem to hold in conflicts cases: selfish promotion of state interests actually erodes the local policy control of other states, and the benefits of experimentation are difficult to realize because the incentive is for states to experiment in the direction of greater promotion of the state's own interest rather than in the direction of lowering total social cost.

\section{FEDERALISM AND CONSTITUTIONAL CONSIDERATIONS}

\section{A. Conflicts and Judicial Federalism}

The early Currie-Baxter exchanges concerning whether conflicts rules ought to be developed at the state or federal level are of a piece with the broader discussion of the relative allocation of power between state and federal courts. The same concerns present in the conflicts context are present in, for example, the criminal context regarding federal habeas corpus review ${ }^{119}$ or in the constitutional context regarding federal jurisdiction to hear claims of constitutional violations under 42 U.S.C. $\S 1983 .{ }^{120}$ In those settings, some scholars argue that the availability of a neutral federal forum is important to prevent state court bias in favor of local policy. In Mitchum v. Foster, the United States Supreme Court itself characterized $\S 1983$ as an expressly authorized exception to the Anti-Injunction Act and described Congress's intent in passing the law as grounded in a skepticism of state courts' neutrality on constitutional issues. ${ }^{121}$ The Court explained, "Th[e] legislative history makes evident that Congress... was concerned that state instrumentalities could not protect [constitutional] rights; it realized that state officers might, in fact, be antipathetic to the vindication of those rights; and it believed that these failings extended to the state courts." 122

118. See id.

119. See Paul M. Bator, Finality in Criminal Law and Federal Habeas Corpus for State Prisoners, 76 HARV. L. REV. 441, 441-43 (1963) (describing the importance of a federal forum for review of state court processes, if not for review of substantive correctness).

120. See Erwin Chemerinsky, Parity Reconsidered: Defining a Role for the Federal Judiciary, 36 UCLA L. REV. 233, 239-55 (1988) (describing the debate over the relative competence of state and federal courts to adjudicate constitutional claims from the time of the Constitutional Convention to the Warren and Burger Courts).

121. 407 U.S. 225,242 (1972).

122. Id. 
But federal courts might be thought of as the more neutral adjudicative body not only because state court judges are apathetic toward federal interests (the Mitchum v. Foster concern), but also because state court judges are likely to actively prefer the interests of their home states. Indeed, something like that concern might lie behind the entire premise of diversity jurisdiction in federal courts. ${ }^{123}$ There are also institutional reasons to think federal court judges are likely to be more neutral among state interests - federal court judges enjoy constitutional protections of their salary and tenure, ${ }^{124}$ while many state court judges face routine elections or reappointment requirements. ${ }^{125}$

If these structural sources of potential bias make federal courts preferable to state courts when enforcement of federal rights at the expense of state interests is at stake, then the same arguments ought to lead us to prefer federal to state courts when there is a clash between state interests in choice of law. In the constitutional context, the concern is that states will under-enforce federal protections, while in the choiceof-law context, the concern is that state courts will over-enforce their home states' law. Both concerns relate to a worry about the ability of state court judges to dispassionately enforce interests that do not cohere with the policy of their home state's government. We can be somewhat less concerned that federal judges will be subject to this kind of bias because of the constitutional mechanisms of Article III designed to insulate federal judges from the vicissitudes of state politics. Also, at the appellate level, federal judges routinely deal with the laws of several states. No circuit has fewer than three states in it, and some have many more, so federal appellate judges are comfortable looking at the laws of several states. ${ }^{126}$

Perhaps one can question whether federal judges are institutionally more neutral than state court judges. After all, even in a world of increasing presidential control over appointments to the Supreme Court and federal courts of appeals, there is still a strong norm of deference to

123. See Barry Friedman, A Revisionist Theory of Abstention, 88 Mich. L. ReV. 530, 541 (1989) ("The premise of diversity jurisdiction is that out-of-state litigants might be subject to bias in state courts, and that a federal trial forum therefore is needed. Supreme Court diversity decisions recognize and rely upon this concern about state court bias.").

124. U.S. CONST. art. III, § 1.

125. Martin H. Redish, Judicial Parity, Litigant Choice, and Democratic Theory: A Comment on Federal Jurisdiction and Constitutional Rights, 36 UCLA L. REV. 329, 333 (1988).

126. See Geographic Boundaries of United States Courts of Appeals and United States District Courts, U.S. COURTS, https://www.uscourts.gov/sites/default/files/u.s._federal_courts_circuit_ map_1.pdf [https://perma.cc/LG27-NZYM] (last visited Jan. 11, 2019). 
local senators when nominating district court judges. ${ }^{127}$ There are sound reasons for this practice. For one, district court judges are considered less ideologically influential than appellate judges, so the basis of selection for district judges becomes less a matter of politics and more a matter of administrative competence. ${ }^{128}$ Because home-state senators retain influence over the appointment of district court judges, one might reasonably expect that federal district court judges, like state court judges, will have strong ties to the states in which they sit and strong loyalty to that state's policy goals (or at a minimum, strong familiarity with the home state's law and perhaps thus sympathy with its positions). ${ }^{129}$ But the question is not whether federal court judges are perfectly institutionally insulated from bias toward state interests. Rather, the relevant question is whether, on the margin, federal or state court judges are more likely to exhibit that bias in a given case. Even if federal judges share in some of the favoritism for home-state policies that we expect of state court judges, there are countervailing institutional protections that make such bias relatively less likely. For example, federal appellate cases are heard by panels of judges, very often from different states. And, as federal cases make their way up the appellate ladder, that process is certain to introduce review from judges from various states, a phenomenon not present in the state court systems. Even if the influence of home-state senators makes the federal forum imperfect, it is still preferable to state courts. What's more, if choice-oflaw questions were resolved at the appellate level, rather than the district court level, then the federal judicial link to a particular home state would become even more attenuated. ${ }^{130}$

\section{B. Congressional Solutions}

Accepting that federal judges are preferable to state court judges for the resolution of conflicts questions, a procedural question remains: by what mechanism would federal courts obtain jurisdiction over interstate

127. See Carl Tobias, Curing the Federal Court Vacancy Crisis, 53 WAKE Forest L. Rev. 883, 894 (2018) ("The Executive relies upon more conventional procedures when suggesting district nominees. For instance, this White House, like recent predecessors, depends greatly on recommendations from home-state officers ....").

128. See id. (noting that the current administration "bases most nominations principally on competence vis-à-vis ability to manage substantial caseloads").

129. See id.; see also Currie, Comments on Babcock v. Jackson, supra note 57, at 1240-41.

130. Especially because, as mentioned, home-state senators have diminishing influence when it comes to appointing appellate level judges, at least in modern presidencies. See generally Tobias, supra note 127. 
conflicts cases? At a high level, one can imagine two mechanisms that would accomplish that end. First, one might imagine a bottom-up solution, with states voluntarily ceding control of choice-of-law issues to federal judges. Second, the solution could instead come from the top down, with Congress or federal courts themselves asserting the authority to decide conflicts questions. This Section examines each of those potential options in more detail.

The initial possibility of a bottom-up approach can probably be dismissed rather quickly. First, as a practical matter, states' decisions to cede control to federal courts causes collective action problems. No individual state will have any incentive to remove conflicts issues from its own state courts, thereby moving those issues from a home-statefriendly forum in state court to a more neutral (and thus marginally more sister-state-friendly) forum in federal court. A state would probably have enough incentive to weaken its own conflicts resolution infrastructure in this way only if it had some assurance that other states were going to move conflicts issues to the federal forum as well. That sort of coordinated sacrifice likely requires some centralized (i.e., federal) action. ${ }^{131}$ Second, there is also a legal issue with the bottom-up approach: by what authority could the states themselves affect federal court jurisdiction? Even if the states wanted to give conflicts determinations to federal judges, perhaps through some sort of certification process, ${ }^{132}$ it is reasonable to think that the states themselves have no power to confer jurisdiction on federal courts to resolve their conflicts questions. Federal court jurisdiction is a matter of federal, and not state, law.

Thus, the best, and perhaps only, hope for a shift in conflicts resolution to the federal forum lies in the top-down approach. This Article proposes one such system. As envisioned in this Article, Congress would create a process whereby state appellate courts would

131. One nonfederal solution that still would involve the coordinated action of many states is an interstate compact. See, e.g., U.S. CONST. art. I, § 10, cl. 3 (limiting states' powers to lay duties, have militaries, engage in war, or enter into compacts with other states). But even an agreement among several states would have to overcome collective action and holdout problems, and states within an interstate compact would presumably lack the authority to alter the jurisdiction of federal courts.

132. 28 U.S.C. $\S 1254(2)$ (2018) contains a provision allowing for the certification of a question of law from a federal court of appeals to the Supreme Court, and most states have statutes allowing certification of state law questions to state supreme courts. For a list of states that entertain certified questions from the federal courts, see 17A Charles Alan Wright, ARThur R. Miller \& EDWARd H. COOPER, Federal PRACTICE AND PROCEDURE $§ 4248$ n.30 (3d ed.), Westlaw (database updated Aug. 2019). One can perhaps imagine a similarly worded statute allowing state courts to certify questions of conflicts of law to a federal district court or court of appeals. See infra Part IV. 
certify choice-of-law questions to the federal courts of appeals for the circuit in which the forum is located. That is, choice-of-law issues that reach the appellate stage in state court should be certified to federal courts of appeals for resolution if the state in question uses a choice-oflaw methodology that is sensitive to state interests or the merits of state laws. As envisioned, state trial courts would make a choice-of-law determination in the first instance. But, when choice-of-law issues reach appellate review, state courts would certify those questions to the federal courts of appeals for de novo review. This Section lays the legal groundwork justifying federal authority to enact such a proposal, while the practicalities of the proposal are taken up in Part IV.

\section{Erie and Klaxon}

The top-down approach is not our system, and the prevailing understanding of how conflicts of law interacts with the Supreme Court's decision in Erie Railroad Co. v. Tompkins ${ }^{133}$ is perhaps the largest impediment to a top-down solution. Erie stands for the proposition that federal courts sitting in diversity apply state substantive law rather than relying on their own exposition of the "general common law."134 In so holding, the Court explained that "Congress has no power to declare substantive rules of common law applicable in a state whether they be local in their nature or 'general' .... And no clause in the Constitution purports to confer such a power upon the federal courts." 135 Given that explanation, a natural question is what to do with the remaining problem of conflicts of law, which has also developed in a common law fashion. If conflicts-of-law rules are substantive for Erie purposes, then federal courts sitting in diversity must follow the conflicts rules of the states in which they sit. ${ }^{136}$ But if conflicts rules regulate procedure, then perhaps there is more flexibility for the development of a separate federal approach.

In Klaxon Co. v. Stentor Electric Manufacturing Co., the Supreme Court held that federal courts sitting in diversity are bound to follow state conflicts law. ${ }^{137}$ The Court explained, "We are of [the] opinion that the prohibition declared in Erie ... extends to the field of conflict of laws. The conflict of laws rules to be applied by the federal court in Delaware

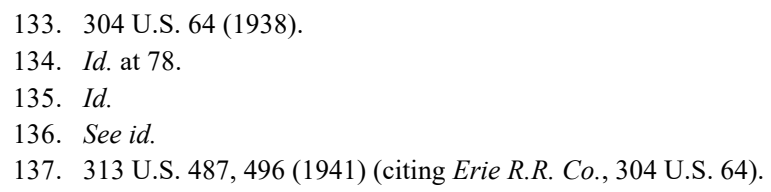


must conform to those prevailing in Delaware's state courts." 138 Thus, we should regard state choice-of-law rules as substantive for Erie purposes, which implies that federal courts sitting in diversity should act as state courts would with regard to choice of law. Under the Erie substance-versus-procedure distinction, this result makes sense: choice of law does not involve rules promulgated in accordance with the Rules Enabling $\mathrm{Act}^{139}$ and conflicts questions are often outcome determinative. ${ }^{140}$ If the Court's goal is to promote Erie's objective of preventing vertical forum shopping, the outcome of Klaxon does seem internally consistent.

If that is so, then perhaps the development of a federal choice-of-law regime might be thought to require overruling Klaxon. Indeed, Baxter, in advocating for the development of federal choice-of-law principles, argues that Klaxon is a poorly reasoned opinion that should be overruled. $^{141}$ Baxter argues that Klaxon overemphasized the dangers of intrastate, vertical forum shopping between federal and state court, and that in so doing it allowed the states to adopt conflicts rules that intentionally subordinated sister-state interests. ${ }^{142}$ Currie, too, when making the case for increased federal control over conflicts issues, considered the possibility that "the rule of the Klaxon case may not survive, and that the federal courts will be freed of compulsion to follow state rules of conflict of laws." 143

But on the logic of Klaxon itself, it is not clear that anything so

138. Id. (citation omitted).

139. See Hanna v. Plumer, 380 U.S. 460, 463-64 (1965) ("The test must be whether a rule really regulates procedure, - the judicial process for enforcing rights and duties recognized by substantive law and for justly administering remedy and redress for disregard or infraction of them." (quoting Sibbach v. Wilson \& Co., 312 U.S. 1, 14 (1941))).

140. See Guar. Tr. Co. of N.Y. v. York, 326 U.S. 99, 110 (1945) (deciding that statutes of limitations are substantive for Erie purposes). Note that the Erie substance-versus-procedure distinction is drawn differently than the same distinction as employed in choice of law. For example, Guaranty Trust held that a statute of limitations was substantive for Erie purposes, but that same limitations period may be procedural for choice of law if the limitations period is not so intertwined with the substantive right so as to be a condition of its vesting at all. See id. ("Such particular rules of local law, however, do not in the slightest change the crucial consideration that if a plea of the statute of limitations would bar recovery in a State court, a federal court ought not to afford recovery."). See also Sun Oil Co. v. Wortman, 486 U.S. 717, 724-25 (1988) (collecting cases in which the forum applied its own statute of limitations even when a different substantive law governed).

141. Baxter, supra note 102, at 41-42.

142. See id. In this sense, Baxter's issue with Klaxon lies with the case's understanding of the Constitution's Full Faith and Credit Clause. He argues that the Clause should not be read, as Klaxon permits, to allow a state to make the judgment that its own interests in a particular case are superior to those of another state. Id.

143. Currie, Change of Venue, supra note 92, at 502. 
drastic as overruling the decision would be necessary to increase the federal courts' role in conflicts matters along the lines that this Article proposes. For one thing, Klaxon purports to be an extension of the Erie doctrine, which relies on the premise that "Congress has no power" to act to make federal common law applicable in the states. ${ }^{144}$ But the Constitution is not similarly silent with regard to conflicts matters. The Full Faith and Credit Clause of Article IV provides that "Full Faith and Credit shall be given in each State to the public Acts, Records, and judicial Proceedings of every other State. And the Congress may by general Laws prescribe the Manner in which such Acts, Records and Proceedings shall be proved, and the Effect thereof." 145 If Congress decided to act on the basis of its Full Faith and Credit authority, then the resulting conflict-of-laws rules might well fall outside of Erie's (and therefore Klaxon's) scope. ${ }^{146}$

What's more, if Congress purported to establish a uniform set of federal rules for conflicts cases pursuant to the authority of the Rules Enabling Act (or comparable legislation), that action too might be permissible under Erie, at least as the decision has come to be understood. Under Justice Scalia's approach in Shady Grove Orthopedic Associates, P.A. v. Allstate Insurance Co. ${ }^{147}$ for example, the test applied to purported federal procedural rules is rather permissive. Justice Scalia acknowledged that most procedural rules "affect[] a litigant's substantive rights," so what matters is whether the rule itself affects only the "manner and the means" of enforcement of substantive rights. ${ }^{148}$ Broadly stated, one might reasonably think that conflicts-of-laws rules qualify as really regulating procedure because they are designed to choose among possible substantive laws that might apply, rather than forming a part of that substantive law themselves. ${ }^{149}$

A procedural mechanism for conflicts questions incorporated into the Federal Rules, however, would apply only to cases in federal court, since state courts follow state procedural rules under Erie. Because choice-oflaw cases involve plaintiffs with state law claims, the Rules Enabling Act approach would leave state courts free to engage in exactly the same kind

144. Erie R.R. Co. v. Tompkins, 304 U.S. 64, 78 (1938).

145. U.S. CONST. art. IV, $\S 1$ (emphasis added); see also infra Section III.B.2.

146. See William Baude, Beyond DOMA: Choice of State Law in Federal Statutes, 64 STAN. L. REV. 1371, 1401-04 (2012) (discussing the possibility of a congressional choice-of-law rule in cases involving the recognition of marriage).

147. 559 U.S. 393 (2010) (plurality opinion).

148. Id. at 407 (quoting Miss. Publ'g Corp. v. Murphree, 326 U.S. 438, 446 (1946)).

149. And, as Justice Scalia notes, the Court has historically rejected every challenge to a federal rule that it has encountered. Id. 
of troubling interest analysis that prompted the desire to give conflicts questions to federal courts in the first place. That partial coverage would accomplish relatively little to address the issues that this Article seeks to remedy, and it is for that reason that this Article justifies a proposed certification procedure using the Full Faith and Credit Clause rather than the Rules Enabling Act.

Separately, this Article's proposal also steers clear of any issues associated with Congress implementing substantive conflicts rules in a top-down manner. Congressional action in the realm of substantive choice of law might preempt inconsistent state conflicts rules, and thus render Klaxon irrelevant, but there might be corresponding concerns about whether such a solution would infringe too greatly on states' sovereignty. States have historically been free to develop their own conflicts systems, and a federal law overriding that development might at least face state resistance, to say nothing of constitutional concerns about Congress's authority to enact such rules.

This Article's procedural innovation is best understood as independent of those substantive choice-of-law concerns and, for that reason, as independent of Klaxon' logic. Klaxon merely requires that federal courts sitting in diversity use the state choice-of-law methodologies of the forum rather than substituting some alternative, federal approach. ${ }^{150}$ But, for this Article's purposes, what is important is that federal courts are applying the methodology; it is less important which particular methodology they apply. A system that involves a procedural preference for federal decision makers would still leave the states free to determine the substantive rules according to which choice of law was to proceed. That sort of deference to state substantive choice of law is consistent with Klaxon, because it does not attempt to substitute federal common law for state law. As the Klaxon Court held, "It is not for the federal courts to thwart... local policies by enforcing an independent 'general law' of conflict of laws." 151 This Article's proposal requires federal courts to do no such thing. Federal courts would still be enforcing the states' conflicts laws rather than a general federal law of conflicts, but it would be only federal courts doing such enforcing when consideration of state interests or purposes was at issue.

In this way, this Article's proposal is in harmony with Klaxon and

150. Klaxon Co. v. Stentor Elec. Mfg. Co., 313 U.S. 487, 496 (1941).

151. Id. Whether Congress, instead of the courts, could thwart local policies by imposing a substantive set of federal choice-of-law rules is a separate matter, resolution of which is not essential to this Article's proposal. 
consistent with the general goals of Erie. There would still remain substantive vertical uniformity between the state and federal courts' choice-of-law rules in a given state - that is, conflicts cases in Delaware would be decided according to Delaware choice-of-law rules in both state and federal courts. Instead, when choice-of-law issues reach state appellate courts, this Article's proposal provides a mechanism to substitute federal decision makers for state decision makers in the hope that such a substitution will lead to application of state substantive conflicts law that is less influenced by bias toward a forum state's interests and policies.

\section{Full Faith and Credit}

It is important to justify the claim that Congress has the power under Article IV to enact legislation that would provide a mechanism for federal court resolution of choice-of-law issues when state interests are at stake. The Supreme Court's Full Faith and Credit jurisprudence proceeds from a background understanding of the Clause as designed to "alter the status of the several states as independent foreign sovereignties, each free to ignore obligations created under the laws or by the judicial proceedings of the others, and to make them integral parts of a single nation." 152 As it has played out in specific cases, the Court has interpreted the goal differently depending on whether the case concerns judgments (which, if the issuing court had jurisdiction, must receive the same effect in a sister state that they would in the issuing state $)^{153}$ or laws. The Full Faith and Credit Clause has never been read to suggest that a sister state must apply the law of another state as if it was its own. "The Full Faith and Credit Clause does not compel 'a state to substitute the statutes of other states for its own statutes dealing with a subject matter concerning which it is competent to legislate." 154

Scholars disagree about the extent of Article IV's implications for choice of law. On the one hand, some scholars suggest that the Full Faith and Credit Clause merely confers upon Congress the ability to implement the requirements of faith and credit defined by the Supreme Court. ${ }^{155}$ But in that view, Congress exceeds its power when it

152. Milwaukee County v. M.E. White Co., 296 U.S. 268, 277 (1935).

153. See, e.g., Fauntleroy v. Lum, 210 U.S. 230, 237-38 (1908) (requiring Mississippi to enforce a Missouri judgment that had clearly misapplied Mississippi's own law).

154. Baker v. Gen. Motors Corp., 522 U.S. 222, 232 (1998) (quoting Pac. Emp'rs Ins. Co. v. Indus. Accident Comm'n of Cal., 306 U.S. 493, 501 (1939)).

155. See Larry Kramer, Same-Sex Marriage, Conflict of Laws, and the Unconstitutional Public 
"legislate[s] away" states' responsibility to give full faith and credit to sister-state laws, specifying "when particular laws should or should not be applied by other states." 156 Critics of Congress's enactment of the Defense of Marriage Act, ${ }^{157}$ which permitted states not to recognize the validity of same-sex marriages validly performed according to the laws of another state, marshalled Full Faith and Credit arguments against that law. ${ }^{158}$ But this Article's proposal does not involve such strong congressional commands. Rather than substantively identifying which among multiple competing state laws should be given effect in the states, a proposal for resolution of choice-of-law issues in the federal courts does not authorize or rule out the possibility of a particular substantive result. Those who questioned DOMA on Full Faith and Credit Clause grounds did so because they argued that the law amounted to congressional permission to give sister states' marriage laws credit that was less than full. This Article's proposal takes no particular position on what the constitutional limits of substantive Full Faith and Credit arewherever those limits are, states will be forced to respect them. States would remain free to craft choice-of-law rules within those limits, but Congress would be acting so as to separate the crafting of those rules by state governments and the enforcement of those rules by the state judiciary.

On the other hand, other scholars take a more expansive view of congressional authority under Article IV, with some going so far as to suggest that the Full Faith and Credit Clause essentially mandates a set of (heretofore unimplemented) choice-of-law rules. ${ }^{159}$ While that reading is contestable, ${ }^{160}$ this Article relies on no such strong understanding of the Clause's effect. Rather, it is enough for this Article's purposes that the clause can be read to authorize congressional action regarding choice of

Policy Exception, 106 YALE L.J. 1965, 2002-03 (1997) (rejecting a reading of the text that confers "plenary authority" upon Congress and instead empowers Congress only to "refine and implement" the requirements of faith and credit as defined by the Supreme Court).

156. Id. at 2003, 2006.

157. Section 2 of the Defense of Marriage Act, 28 U.S.C. $\S 1738$ C (2018), was the primary target for Full Faith and Credit critiques.

158. See, e.g., H.R. REP. No. 104-664, at 70 (1996) (citing Letter from Laurence H. Tribe, Professor, Harvard Law Sch., to Sen. Edward Kennedy (May 24, 1996), reprinted in 142 ConG. REC. S5931-33 (daily ed. June 6, 1996) (statement of Sen. Kennedy)).

159. See Laycock, supra note 73 , at 290-95 (arguing that the word "shall" creates a selfexecuting obligation that mandates Full Faith and Credit be given to each state's acts, records, and judicial proceedings).

160. See, e.g., Ralph U. Whitten, The Original Understanding of the Full Faith and Credit Clause and the Defense of Marriage Act, 32 CREIGHTON L. REV. 255, 346-72 (1998) (rebutting Laycock's argument that the Clause mandates choice-of-law rules). 
law, without mandating that action. That reading of the Clause would seem to have support among those who focus on the text's original meaning, understanding the first part of the Clause as a substantive evidentiary command to the states ("Full Faith and Credit shall be given"), ${ }^{161}$ while leaving open to Congress in the Effects Clause the ability to craft more substantive national rules ("Congress may by general Laws prescribe ... the Effect thereof"). ${ }^{162}$

Indeed, from this perspective, one possible objection to this Article's proposal is that it is too noncommittal given the Clause's text. That is, perhaps "Effect" as used in the Clause means only substantive effect, and therefore a statute that merely shifted the locus of choice-of-law decisional authority without specifically prescribing an effect is ultra vires. There are two potential responses to such an objection. First, while the second half of this section of Article IV of the Constitution is often called the "Effects Clause," the Constitution also provides that Congress may "prescribe the Manner" by which "Acts, Records, or judicial Proceedings shall be proved." "163 Inclusion of congressional authority over both "Manner" and "Effect" would seem to encompass this Article's procedural proposal.

But on a view emphasizing original understanding, perhaps the "Manner" part of the clause is best read as referring only to the evidentiary status of other state "Acts, Records, or judicial Proceedings." "164 That is, perhaps the "Manner" clause provides for congressional authority over procedures to establish the validity of sisterstate laws as a matter of evidence, while the "Effects" clause provides for congressional authority over substantive effect. If so, this Article's proposal might initially appear to fall outside the scope of either of those grants of congressional authority. But a second response to this line of criticism is that the greater congressional power to legislate regarding the effect of a sister-state's law includes the lesser, less intrusive authority to permit state autonomy with regard to substantive choice-of-law rules

161. U.S. CONST. art. IV, § 1 .

162. Id. See, e.g., Stephen E. Sachs, Full Faith and Credit in the Early Congress, 95 VA. L. REV. 1201, 1208-09 (2009) (arguing for an "evidentiary interpretation of the Clause" that "leaves the field open for deliberation and choice over the structure of our federal system"); David E. Engdahl, The Classic Rule of Faith and Credit, 118 YALE L.J. 1584, 1655 (2009) ("Under the 'classic rule' of faith and credit, the only provisions of federal law requiring that any of the United States give effect (as distinguished from prima facie evidentiary sufficiency) to sister-state 'Acts,' 'Records,' or 'judicial Proceedings' are those provisions (if any) that Congress has legislatively prescribed.").

163. U.S. CONST. art. IV, § 1.

164. Id. 
while reserving federal authority over their implementation. If the Full Faith and Credit Clause should properly be understood to provide "that Congress be granted plenary power to determine the extent of faith and credit to be accorded state acts, records, and proceedings in sister states," 165 then presumably that authority extends to "legislative choice over the structure of our federal system" "166 that includes the mechanisms by which interstate choice-of-law questions make their way through the courts.

Finally and more broadly, congressional action in this area is consistent with the Supreme Court's understanding of the animating spirit of the Full Faith and Credit Clause - namely "to make [the states] integral parts of a single nation."167 It furthers that goal by preserving state autonomy over which choice-of-law approach they will follow while reducing opportunities for state actors to play favorites in interstate disputes. That sort of give and take is consistent with the federalism values that the Supreme Court ascribes to the Clause and strikes a balance between the status quo of independent state authority and a potentially overbearing substantive congressional mandate.

\section{A POTENTIAL PATH FORWARD}

As we have seen, there are good reasons to prefer that federal, rather than state court, judges make the choice-of-law decisions in conflicts cases. Both practically and constitutionally speaking, however, there are good reasons to think that congressional action is necessary to achieve that result. This Part will briefly sketch the mechanics of one possible form of congressional action permitting certification of choice-of-law questions from state courts to federal courts of appeals.

\section{A. State-Federal Certification}

Certification, in its most common form, arises when federal courts ask state supreme courts for an authoritative interpretation of state law. ${ }^{168}$ The availability of the procedure is a function of state law. ${ }^{169}$ Where

\footnotetext{
165. Daniel A. Crane, The Original Understanding of the "Effects Clause" of Article IV Section 1 and Implications for the Defense of Marriage Act, 6 GEO. MASON L. REV. 307, 336 (1998).

166. Sachs, supra note 162 , at 1202.

167. Milwaukee County v. M.E. White Co., 296 U.S. 268, 277 (1935).

168. WRIGHT, MILLER \& COOPER, supra note $132, \S 4248$.

169. See id. (" $[\mathrm{I}] \mathrm{t}$ was and is clear that a federal court cannot compel a state court to answer questions in the absence of a state procedure."). Again, this confirms the necessity of a top-down approach to these issues. Just as federal courts have no power to compel state courts to answer
} 
available, certification has largely come to replace Pullman abstention as a more economical solution to the potential waste of resources involved in a federal court basing its decision on a new or questionable construction of state law. ${ }^{170}$ State courts generally have discretion whether to answer a certified question, and federal courts treat themselves as bound by the state court's interpretation of state law. ${ }^{171}$

A hypothetical choice-of-law certification procedure could work much the same way. Congress could enact a statute requiring that states whose conflicts rules involve consideration of the relative interests or merits of state law certify choice-of-law questions to the federal court of appeals for the circuit in which the forum is located. Federal courts of appeals are preferable to federal district courts for adjudication of these issues because appellate judges are less likely to have significant loyalty to the policies of a single state, as described above. ${ }^{172}$ As with existing certification, the certifying court would provide the necessary background factual information to allow the court to consider the questions of law at issue. ${ }^{173}$ Congressional authority for enacting a statute requiring certification would come from the Full Faith and Credit Clause - such certification of choice-of-law questions would be a part of the "Effect" of the "Acts" of the states in sister-state courts. ${ }^{174}$ Unlike the federal-state certification statutes that exist now, this review by courts of appeals would not be discretionary.

Formally, then, such certification would involve a state court faced with a choice-of-law question certifying that question to a federal court of appeals. Because Congress would have provided for such activity by statute, the choice-of-law question would become a matter of federal rather than state conflicts law, and so would be authoritatively resolved by a federal court. The fact that choice of law then becomes a matter of federal law is crucial, for it would be odd to certify to federal courts a question of state (conflicts) law. If choice of law was a state law question, then state courts would be free to overrule federal courts' resolution of the conflicts issue after having certified the question to them initially. As mentioned, Congress could leave the states some

questions of law absent some enabling statute, state courts and legislatures would be powerless to create jurisdiction in the federal courts to answer questions of state conflicts law.

170. See Jonathan Remy Nash, Examining the Power of Federal Courts to Certify Questions of State Law, 88 CORNELL L. REV. 1672, 1681-86 (2003) (discussing the evolution of Pullman abstention and certification).

171. Id. at 1695 .

172. See supra Section III.A.

173. See Nash, supra note 170 , at 1693.

174. U.S. CONST. art. IV, $\S 1$. 
discretion as to the substance of the conflicts approach that they wanted to apply to cases in their courts, remaining agnostic between use of the First Restatement, Second Restatement, interest analysis, better law, or some other method (perhaps the finalized Third Restatement). ${ }^{175}$ States would choose to adopt one conflict-of-laws regime or another, but determinations of which law applies under whatever regime a particular state selected would be a matter of federal law.

There are at least three potential concerns with this proposal worth discussing. First, one might worry that instituting a process of federal court control over choice-of-law questions communicates an unsettling distrust of the state courts. After all, the baseline in American jurisprudence is that state and federal courts have concurrent jurisdiction and that state courts are as competent as federal courts at resolving issues of federal law. ${ }^{176}$ The choice is ordinarily left to litigants to decide whether to pursue legal claims in state or federal court. But putting authority over conflicts questions exclusively in the hands of federal courts is different than, for example, opening up a federal forum for constitutional claims.

In the constitutional context, we think that allowing litigants access to federal court provides litigants with an opportunity to bring their constitutional claims to a neutral federal forum. ${ }^{177}$ Litigants in conflicts cases, on the other hand, have every incentive to seek out the state court forum most likely to exhibit bias in favor of the litigant's preferred legal rule. In constitutional law, then, the availability of a federal forum is enough to encourage litigants toward a neutral forum. But in conflicts, merely making a neutral forum available does not go far enough. Thus, choice-of-law questions uniquely call for a federal solution. Moreover, any distrust this procedure communicates is the same sort of distrust that arguably lies behind the entire premise of federal diversity jurisdiction. ${ }^{178}$

Second, a potential stumbling block for this proposal is the increase in workload for the federal courts of appeals. As a baseline, the federal

175. See infra Part II.

176. See, e.g., Gulf Offshore Co. v. Mobil Oil Corp., 453 U.S. 473, 478 (1981) ("[T]he Court begins with the presumption that state courts enjoy concurrent jurisdiction. Congress, however, may confine jurisdiction to the federal courts either explicitly or implicitly.") (citations omitted).

177. See generally Chemerinsky, supra note 120 (discussing the longstanding concerns about the ability of state courts to protect constitutional rights).

178. See Bank of U.S. v. Deveaux, 9 U.S. (5 Cranch) 61, 87 (1809) ("However, true the fact may be, that the tribunals of the states will administer justice as impartially as those of the nation . . . it is not less true that the constitution itself... entertains apprehensions on this subject... [and so] has established national tribunals for the decision of controversies between aliens and a citizen, or between citizens of different states."). 
appellate courts saw 49,276 cases filed in 2018. ${ }^{179}$ The best available data on conflicts cases lists 5,242 such cases posted on Westlaw in $2018 .^{180}$ That number, however, does not include a significant quantity of state trial court cases that do not make it to Westlaw. The number of choice-of-law cases in state appellate courts in 2018 was $957 .{ }^{181}$ Assuming that litigants in state court appealed choice-of-law cases at rates similar to litigants in federal court, these numbers imply that an additional 7,000 cases decided in state trial courts may be unaccounted for in the survey. ${ }^{182}$

Increasing the caseload of federal courts of appeals by over 7,000 cases each year would be a significant burden. If a court of appeals made a choice-of-law decision in each of those cases, choice of law would represent approximately 13\% of the work of courts of appeals. Two considerations mitigate that concern. First, the courts of appeals would retain discretion over the management of these cases. Because choice-of-law issues are outcome determinative, three-judge panels in the courts of appeals must make the decisions. ${ }^{183}$ But there is no reason the certified choice-of-law questions would require, for example, full briefing or oral argument. The decisions could be treated in a manner similar to aspects of the motions practice in the courts of appeals, which often involves limited briefing and judgments rendered solely on the papers.

Second, and more substantively, a huge number of choice-of-law decisions could be eliminated if certification to federal courts of appeals was available only from state appellate courts. The number of choice-oflaw cases decided in state appellate courts in 2018 was under 1,000, so the burden felt by the federal appellate judiciary of such a proposal would be significantly smaller. ${ }^{184}$ When combined with the practical considerations discussed above, the proposal seems manageable overall. An increased workload of around 1,000 motion-like decisions by federal

179. Judicial Business 2018, U.S. COURTS, https://www.uscourts.gov/statistics-reports/judicialbusiness-2018 [https://perma.cc/YJP5-K7SP] (last visited Feb. 4, 2020).

180. Symeonides, Choice of Law in 2018, supra note 81, at 3.

181. Id.

182. Note that the work of the federal courts of appeals would only increase by the number of state court conflicts cases it was forced to decide. As envisioned in this Article, federal district courts would still make initial choice-of-law determinations for cases filed in federal court, and the appellate review process for such cases would remain unchanged. The district court's choice-of-law decision would be reviewable as part of the final judgment of the district court.

183. 28 U.S.C. $\S 46$ (b) (2018). That choice-of-law issues are outcome determinative also influences how the certification procedure proposed in this Article would fit within the "case or controversy" requirement of Article III, which is discussed below.

184. Symeonides, Choice of Law in 2018, supra note 81, at 3. 
courts of appeals seems reasonable given the benefits of federal court determination of important choice-of-law issues. Restricting the availability of choice-of-law certification to the state appellate stage also has ancillary benefits. For one thing, such cases will have already undergone significant factual development, so federal courts of appeals would have the context necessary to make a relatively speedy informed determination.

Third, any such certification process must ensure that the federal courts are not tasked with providing advisory opinions. Under the Constitution, the judicial power of the United States extends to "Cases" and "Controversies." " As the Supreme Court explained, "A justiciable controversy is ... distinguished from a difference or dispute of a hypothetical or abstract character; from one that is academic or moot. The controversy must be definite and concrete, touching the legal relations of parties having adverse legal interests."186 The Court insisted that a controversy appropriate for judicial resolution under Article III must "admit[] of specific relief through a decree of a conclusive character, as distinguished from an opinion advising what the law would be upon a hypothetical state of facts." 187 If resolution of a choice-of-law issue is too far removed from the substantive reality of the case, then perhaps any federal court judgment on that issue would be merely advisory.

There are good reasons, however, to think that this worry is not fatal to this Article's proposal. For one, conflicts determinations are outcome determinative - they determine which among two or more conflicting laws will apply to a given dispute. ${ }^{188}$ That there is a conflict of law at all implies that the choice-of-law issue will involve a meaningful choice between applications of substantively different alternatives. Also, as mentioned above, if certification to a federal court was only available once cases reached appellate stage in state courts, then there would be a robust factual record for the federal courts to consider as they evaluated a choice-of-law question. That grounding in a concrete, factual reality addresses concerns about federal courts being asked to render a decision "advising what the law would be upon a hypothetical set of facts."189 Indeed, most state certification procedures require a certification order to

185. U.S. CONST. art. III, $\S 2$, cl. 1.

186. Aetna Life Ins. Co. of Hartford v. Haworth, 300 U.S. 227, 240-41 (1937) (citations omitted).

187. Id. at 241 (citations omitted).

188. See discussion infra Section IV.A.

189. Aetna Life Ins. Co., 300 U.S. at 241. 
include a statement of all "the facts relevant to the question, showing fully the nature of the controversy out of which the question arose." ${ }^{\prime 190}$ It seems likely that any choice-of-law question certified at the appellate stage could comply with a similar requirement.

\section{B. Appellate Review}

A final topic to consider in association with this proposal is how appellate review of choice-of-law cases would operate. For cases originating in the federal courts the system is unchanged, so choice of law would continue to be a potential basis for appellate review of a final judgment of a lower court. The state court process is a bit more complex. As envisioned, state appellate courts would certify a choice-oflaw question to federal courts of appeals for a binding determination of the choice-of-law questions in a particular case. Because Congress would have acted to federalize choice of law, the certified question is best thought of as a matter of federal (conflicts) law. State intermediate and supreme courts, then, would not have interpretive authority on the conflicts questions vis-à-vis the federal courts of appeals. But, as usual, litigants would be free to seek review of a court of appeals conflicts decision as an appeal to the United States Supreme Court once the state court case reached the highest state court. ${ }^{191}$

It is also important to clarify that, as a formal matter, certification of choice-of-law questions to federal courts of appeals would not violate the Rooker-Feldman doctrine. In general, outside of the habeas context, Rooker-Feldman requires that the only federal court review of state court decisions is via the United States Supreme Court. ${ }^{192}$ But, as it has done in the context of petitions for writs of habeas corpus, Congress can authorize federal court review of state court judgments. Even setting aside Congress's authority to provide for federal court review, there are good reasons for thinking that the sort of certification envisioned here does not implicate the core concern of Rooker-Feldman. Rooker-

190. UNIF. CERTIFICATION OF QUESTIONS OF LAW [ACT] [RULE] § 6(a)(2) (amended 1995), 12 U.L.A. 82 (1996). See, e.g., Ill. Sup. CT. R. 20(b)(2) (“A certification order shall contain ... a statement of all facts relevant to the questions certified and showing fully the nature of the controversy in which the questions arose."); KAN. STAT. ANN. § 60-3203 (West 2008) (“A certification order shall set forth ... a statement of all facts relevant to the questions certified and showing fully the nature of the controversy in which the questions arose.").

191. See 28 U.S.C. $\S 1257$ (a) (2018).

192. See D.C. Court of Appeals v. Feldman, 460 U.S. 462, 482 (1983) (“[A] United States District Court has no authority to review final judgments of a state court in judicial proceedings. Review of such judgments may be had only in this Court.”). 
Feldman involves a subsequent action filed by a losing party in federal district court review of an adverse state court judgment. ${ }^{193}$ Certification of choice-of-law questions would involve state appellate courts, rather than state court "losers," initiating the request for a ruling.

Another way to think about the potential Rooker-Feldman concern is to consider formally how jurisdiction interacts with the certification process. Even in familiar contexts, that is a difficult question. ${ }^{194}$ Professor Jonathan Remy Nash suggests that we can think of certification as involving either a "unitary" or "binary" conception of federal appellate jurisdiction. ${ }^{195}$ The unitary conception would imply that certification involves something like a transfer of the case from state to federal court for the limited purpose of deciding the choice-of-law issue. That conception would seem to eliminate Rooker-Feldman concerns, because the federal court review would not result from "the losing party in state court fil[ing] suit in federal court after the state proceedings ended." 196

On a binary conception, the court accepting certification is actually accepting jurisdiction over a separate "case" distinct from the case pending before the certifying court. ${ }^{197}$ The Rooker-Feldman issue is probably closer under this framework because it would involve the court of appeals accepting jurisdiction over a case for the purposes of reviewing a state court conflicts decision. But the basis for the case would be a certified request from a state appellate court, rather than the filing activity of a state court loser. Thus, even on the binary conception, it seems acceptable for Congress to create a basis for original jurisdiction in federal courts of appeals over cases certified by state appellate courts for resolution of choice-of-law issues. That situation does not implicate the narrow circumstances of Rooker-Feldman, in which a losing state court litigant herself invites federal court review of a state court's final judgment.

193. See Exxon Mobil Corp. v. Saudi Basic Indus. Corp., 544 U.S. 280, 284 (2005).

194. The basis of jurisdiction in existing certification processes (where federal courts certify questions of state law to state supreme courts) is not definitively understood. See Nash, supra note 170, at 1701-11. As such, the discussion of jurisdiction in this hypothetical certification situation is necessarily a bit speculative.

195. Id.

196. Exxon Mobil Corp., 544 U.S. at 291

197. Nash, supra note 170, at 1701. 


\section{CONCLUSION}

The Third Restatement of Conflicts of Law provides a concrete opportunity for serious scholarly discussion of choice of law. This Article urges that procedural considerations become a larger part of that discussion. Choice of law has come to involve a standards-based consideration of a variety of issues concerning the nuances of state policy choices and the intensity of state interests in those policies. Any such consideration leads naturally to the tendency for a state to overstate its own policy interests and to discount the interests of sister states. Federal resolution of choice-of-law issues is thus attractive because federal court judges are more insulated from this bias. A procedure that required state courts, at the appellate review stage, to certify choice-oflaw issues to federal courts of appeals would help to mitigate those concerns. Such a procedure would be constitutionally permissible and consistent with the broad spirit of our federal system. 